Review

\title{
Drug Delivery Applications of Three-Dimensional Printed (3DP) Mesoporous Scaffolds
}

\author{
Tania Limongi ${ }^{1, * \mathbb{C}}$, Francesca Susa ${ }^{1}$, Marco Allione ${ }^{2}$ and Enzo di Fabrizio ${ }^{1}$ \\ 1 Dipartimento di Scienza Applicata e Tecnologia, Politecnico di Torino, Corso Duca Degli Abruzzi 24, \\ 10129 Torino, Italy; francesca.susa@polito.it (F.S.); enzo.difabrizio@polito.it (E.d.F.) \\ 2 SMILEs Lab, PSE Division, King Abdullah University of Science and Technology, \\ Thuwal 23955-6900, Saudi Arabia; marco.allione@kaust.edu.sa \\ * Correspondence: tania.limongi@polito.it
}

Received: 30 June 2020; Accepted: 5 September 2020; Published: 8 September 2020

\begin{abstract}
Mesoporous materials are structures characterized by a well-ordered large pore system with uniform porous dimensions ranging between 2 and $50 \mathrm{~nm}$. Typical samples are zeolite, carbon molecular sieves, porous metal oxides, organic and inorganic porous hybrid and pillared materials, silica clathrate and clathrate hydrates compounds. Improvement in biochemistry and materials science led to the design and implementation of different types of porous materials ranging from rigid to soft two-dimensional (2D) and three-dimensional (3D) skeletons. The present review focuses on the use of three-dimensional printed (3DP) mesoporous scaffolds suitable for a wide range of drug delivery applications, due to their intrinsic high surface area and high pore volume. In the first part, the importance of the porosity of materials employed for drug delivery application was discussed focusing on mesoporous materials. At the end of the introduction, hard and soft templating synthesis for the realization of ordered 2D/3D mesostructured porous materials were described. In the second part, 3DP fabrication techniques, including fused deposition modelling, material jetting as inkjet printing, electron beam melting, selective laser sintering, stereolithography and digital light processing, electrospinning, and two-photon polymerization were described. In the last section, through recent bibliographic research, a wide number of 3D printed mesoporous materials, for in vitro and in vivo drug delivery applications, most of which relate to bone cells and tissues, were presented and summarized in a table in which all the technical and bibliographical details were reported. This review highlights, to a very cross-sectional audience, how the interdisciplinarity of certain branches of knowledge, as those of materials science and nano-microfabrication are, represent a growing valuable aid in the advanced forum for the science and technology of pharmaceutics and biopharmaceutics.
\end{abstract}

Keywords: drug delivery; three-dimensional porous scaffolds; electron beam melting; selective laser sintering; stereolithography; electrospinning; two-photon polymerization; osteogenesis; antibiotics; anti-inflammatory

\section{Introduction}

Recently, one of the main thrusts of the micro and nano technologies application in the biomedical and clinical field has certainly been observed in the pharmaceutical drug delivery technologies optimization. Whether it is based on active or passive drug delivery, the way in which drugs are delivered substantially impact their efficacy and toxicity affecting their biocompatibility, pharmacokinetics, and pharmacodynamics. Drugs and active molecules can be introduced into the body via a number of administration routes such as buccal/sublingual, nasal, ocular, oral, pulmonary, anal/vaginal, transdermal and parenteral drug delivery [1-3]. Since a high percentage of the active 
pharmaceutical ingredients settled by the pharmaceutical production are precluded for a classical administration route, due to their low bioavailability [4], novel technologies assist modern drug delivery. As a result, an increase is observed in the effectiveness and reduction of side effects of the formulations in relation to patient compliance and costs reduction. In the past years, many drug delivery systems as organic and inorganic micro- and nanoparticulated systems as nanoparticles, micelles, liposomes, extracellular vesicles, nanotubes, metal-organic frameworks (MOF) and hydrogels have been used to deliver drugs at their therapeutic concentration to specific cell types and tissues [5-8]. Both material and design should be taken into account when optimizing a drug delivery carrier able to guarantee tuneable release (sustained, controlled, or pulsed), to act as a temporary reservoir, to increase the solubility of hydrophobic formulations, to float in the gastrointestinal tract and to protect the biological cargo from degradation [9].

Porous carriers have been successfully used as drug delivery matrices for their surface properties, high surface area and tuneable pore dimensions $[10,11]$. According to their pore sizes, porous materials are classified into three different categories, namely microporous, mesoporous, and macroporous $[9,12]$. Microporous materials such as MOFs and zeolites, are characterized by a well-interconnected network of pores less than $2 \mathrm{~nm}$ in size and high thermal stability and catalytic activity [13]. In macroporous materials, pores dimension ranges between 50 and $1000 \mathrm{~nm}$ [14] while in mesoporous materials pore size is between 2 to $50 \mathrm{~nm}$ [15]. In more details, mesoporous materials with a narrow pore dimension distribution and high surface area can be considered valuable candidates in drug delivery applications [16,17]. In the wide category of mesoporous, many materials are included such as mesoporous silica, hydroxyapatite and carbon, hydrogel and nanogel, metal and metal-doped nanoparticles. These materials have great versatility since their actions can be regulated by tuning the chemical environment optimizing the loading and consequent release of the chosen drug [18-20]. The drug incorporation into a mesoporous material is usually carried out by embedding the matrix in a concentrated solution of the drug and by a successive drying step. The size of the absorbable molecule (from small active molecules to proteins) is related to the dimension of the pore, and generally, a pore/drug size ratio $>1$ allows the adsorption of active molecules inside the pores. By using polymeric structure-directing agents, varying the chain length of surfactant or solubilizing supplementary substances into micelles, mesopores sizes can be adjusted from some nanometres to several tens of nanometers [21].

Recent advancement in micro/nano-fabrication techniques, materials science, chemistry and pharmacology has allowed the development of a number of mesoporous materials for drug delivery application characterized by evident structural advancement such as tuneable pore sizes, different grade of skeleton rigidity and two/three dimensional (2D-3D) architectures arrangement [22-26].

Hard (nanocasting) or soft templating approaches are applied to produce ordered mesostructured porous materials. The templated synthesis usually requires three successive steps: template preparation, template-directed synthesis and template removal. Hard templating leads to very robust structures containing several constituents as carbon, and metals (oxides, nitrides and sulphides) [27,28]. It is a synthetic method based on the deposition of the targeted materials into the narrowed spaces of the template, resulting in a reversed copy of the mold. The pores of these templates are soaked with a precursor of the looked-for product (e.g., a metal salt for metal oxides) which is in situ thermally transformed to the final product. When the template is removed, mesoporous material remains as the negative replica of the hard template [29].

Soft-templating techniques allow direct synthesis of porous materials through block copolymers including blocks of ionic and non-ionic oligomers, amphiphilic surfactants employed as structure-directing agents (SDAs) and through the addition of precursors as metal salts for metal oxide nanomaterials and organosilanes or triethoxysilane for $\mathrm{SiO}_{2}$-based nanomaterials. Soft-templating techniques are those in which small sub-units self-assemble to define the final structure, which is an aggregate of these starting units, which are not embedded in other matrices or removed as in the techniques described above. Upon self-assembly in a solvent, a micellar structure is realized by the 
fact that the hydrophobic sides of the molecules of the amphiphilic surfactants point inward and the hydrophilic ones outward in case the solvent is polar, while the opposite occurs if the solvent is non-polar. After this step, micelles are functionalized on their external corona structure using functional groups, frequently polymeric oligomers. Finally, it is the cross-linking of these external terminations which assemble the micelles in a mesoporous superstructure [30].

Producing porous hierarchical materials by integrating macropores in mesoporous tools manifestly increases their practical drug delivery applicability since macropores increase mass transport decreasing diffusion restraints characterizing purely mesoporous materials, while the mesopores empower great surface area [31,32].

Many methodologies have been optimized to engineer the hierarchically structured mesoporous solutions. The dual-templating synthesis method, applying colloidal crystal (opal) hard-templating and soft-templating techniques, is employed for realizing, as schematized in Figure 1, 3D macro/mesoporous materials for a wide range of applications, including the drug delivery ones $[33,34]$.

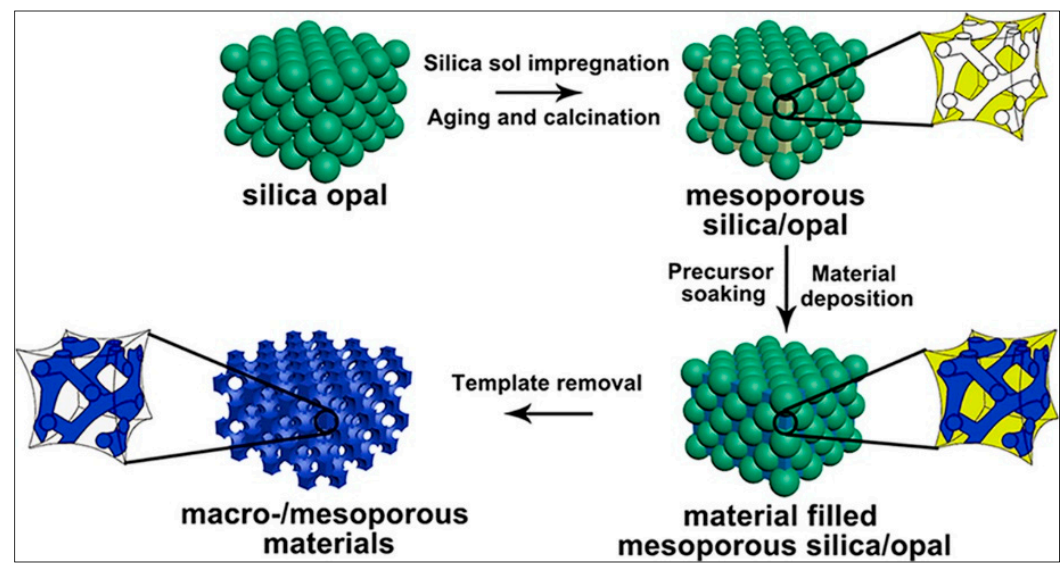

Figure 1. Schematic representation of 3D macro/mesoporous materials preparation reproduced with permission from [34], Chemistry of Materials, 2018.

\section{3D Printed (3DP) Mesoporous Scaffolds Fabrication Technique}

The idea of realizing a macroscopic object via a bottom-up approach has been attractive for a long time but recently, the advancement of both the materials to be used and the techniques to be exploited have made possible the fabrication of 3D printers able to produce any shape in many different natural [35], synthetic, plastic and metallic materials, at variable size scales and with potentially very high accuracy in positioning [36-38]. This has pushed some researchers towards the idea to explore the possibility to use these techniques to realize solutions with different designs, characterized by being made of different types of mesoporous materials [21]. 3D porous substrates, used with or without further functionalization or engineering, are used more and more frequently in in vitro and in vivo drug delivery studies to assist cell growth or tissue regeneration ensuring the right degree of asepticity and differentiation [39-41].

2D and 3D printing tools are appealing for drug delivery applications since state-of-the-art equipment allows the deposition of liquid, gel, and solid constituents enclosing a wide range of pharmaceutics according to predefined schemes. The layer-by-layer assembling mode to print scaffold allows exact control of the design and of the geometry of the internal pores system, which consequently leads to tune the strength of the final products $[42,43]$.

3DP technology can successfully assist engineers, pharmacologists and clinicians in the design and realization of 3D mesoporous scaffolds to be used for different medical applications such as tissue engineering and regenerative medicine implants characterized by the adjustable loading and unloading activity of pharmacologically active substances such as, antibiotics, growth and differentiation factors (Figure 2) [44]. 


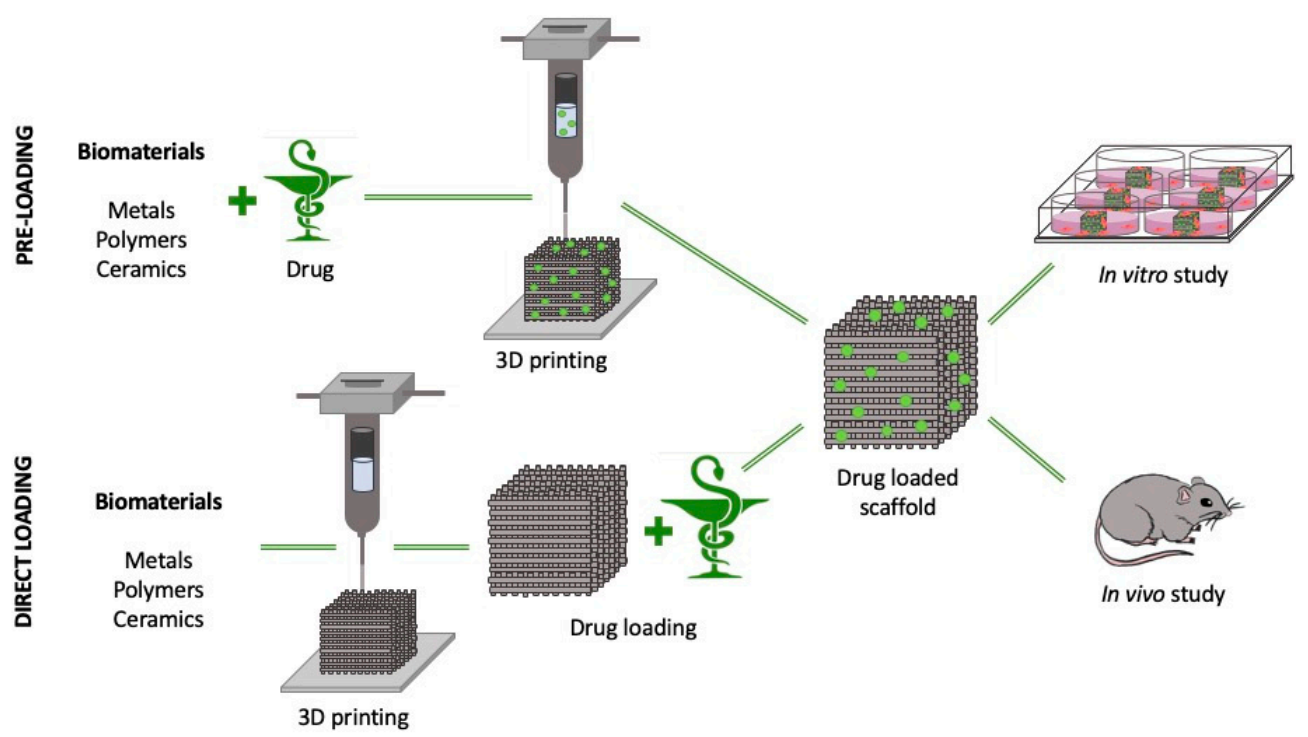

Figure 2. Schematic layout summarizing pre-loading and direct loading 3DP porous substrate fabrication for in vitro and in vivo drug delivery applications.

These active substances can be incorporated inside the mesoporous 3D structures in two different main steps: during the manufacturing process (pre-loading, PL) by mixing the substances with the printable material and then proceeding with the 3DP technique in mild conditions (i.e., electrospinning or inkjet printing), or at the end of the printing step (direct loading, DL), by soaking the 3D-printed scaffold in a solution of the molecule to be loaded as reported for bone morphogenetic protein-2 (BMP-2) mesoporous calcium silicate (MesoCS) 3D-printed scaffold [45]. PL methods are usually applied for the production of scaffolds able to locally deliver antibiotiotics [46], but unfortunately, antibiotics such as those of the cephalosporin family have significantly reduced efficiency when exposed to heat and, consequently, the DL method is definitely applied to sensitive molecules when the 3DP process is carried out at high temperatures or pressures [47].

There are many 3DP strategies available to the scientific community that allow the realization of mesoporous scaffolds under computer aids combining different processes and materials like carbon nanotubes, nanoparticles, nanofibers, polymers with active biomolecules with or without live cells. These 3DP fabrication techniques, as summarized in Figure 3, include fused deposition modeling (FDM), material jetting as inkjet printing (IP), electron beam melting (EBM), selective laser sintering (SLS), stereolithography (SLA) and digital light processing, electrospinning, and two-photon polymerization (TPP).

\subsection{Fused Deposition Modeling}

FDM is one of the most inexpensive nozzle-based deposition systems that allows direct printing of 3D CAD designed layer by layer objects. Thermoplastic degradable (polylactic acid, PLA, poly(e-caprolactone), PCL, polyvinyl alcohol, PVA) and non-degradable (acrylo-nitrile butadiene styrene, ABS, ethylene vinyl acetate, EVA, poly methyl methacrylate, PMMA) polymer filament are pushed into the heater block to melt before extruding from a high-temperature nozzle solidifying onto the previous layer on the build plate [48].

The easiest method of loading target drugs into the thermoplastic polymer filament is the impregnation obtained leaving the just printed device in a concentrated drug solution (mostly ethanol or methanol) followed by a drying step $[49,50]$.

\subsection{Inkjet Printing}

The inkjet-based non-contact printing technology reproduces digital patterns with tiny ink drops through thermal, piezoelectric and magnetic approaches. The thermal stimulation, reaching until 
100-300 ${ }^{\circ} \mathrm{C}$, nucleates a bubble and directly leads to droplet expulsion from the printhead. The size of droplets is related to the temperature gradient and ink viscosity employed. Likewise, the ink drop generation can be produced by the pulse strain and acoustic waves generated from a piezoelectric actuator and larger size ink droplets can be produced by means of electromagnetic filed [51-53].

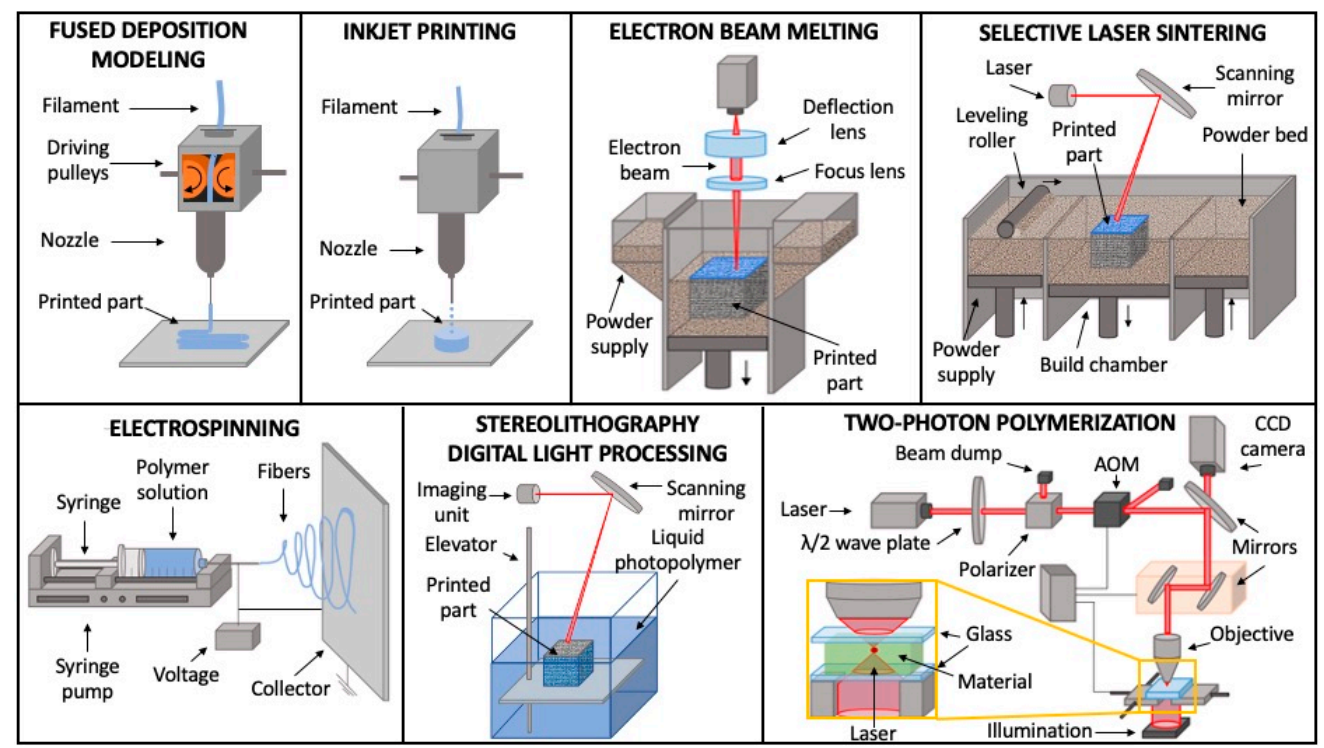

Figure 3. Schematic illustrations of the most diffused 3D printing fabrication techniques for porous scaffolds manufacturing: fused deposition modeling, inkjet printing, electron beam melting, selective laser sintering, stereolithography, electrospinning, two-photon polymerization.

\subsection{Electron Beam Melting}

EBM is a modern fast solution to manufacture metal parts on a layer-by-layer basis through an electron beam that, bombarding the metal powders, melts them, constructing 3D geometries. This technique compared with ones using a laser, are characterized by high energy utilization and material absorption rate, improved stability, and reduced maintenance fees [54]. Although this technique is successfully used for the realization of porous orthopedic and dental implants made of metallic biomedical alloys as Ti6Al4V [55], to date, there are no applications of EBM for the production of 3D printed mesoporous devices for drug delivery application. This is due to the fact that these kinds of scaffolds are characterized by large surface roughness since EBM microfabrication accuracy ranges from $0.3-0.4 \mathrm{~mm}$.

\subsection{Selective Laser Sintering}

SLS operates without a mold through a computer-controlled laser beam, powder bed, a piston assuring a vertical movement, and a roller to spread continuously powder layers [55]. This technique allows the realization of polymeric, metallic, and ceramic parts. SLS implies solid and semisolid consolidation procedures at a sintering temperature usually lower than the melting point. In the semisolid process suitable for treating low melting point polymer, as PCL, polyglycolide, PLA and poly(L-lactic) acid (PLLA), partially melted powder particles produce a certain volume of the liquid phase, which glues other solid elements. Microsphere-based hydroxyapatite (HA)/PCL scaffolds realized by SLS, shows a highly ordered porous structure [56]. Polyamide/HA composite platforms with porosities ranging from $40 \%$ to $70 \%$ and with a maximum tensile strength of $21.4 \mathrm{MPa}$ were obtained by SLS $[55,57]$. Although the low near-infrared laser absorptivity of oxide ceramics, the direct SLS of ceramics throughout powder coating adds to the low melting point or composites ceramics has been done [58]. Many sacrificial binders as waxes, thermoplastics, long-chain fatty acids or sometimes a combination of binders as thermoset/semi-crystalline PA-11 or wax/PMMA are used for the 
realization of porous $3 \mathrm{D}$ structured materials as graphite and composite ceramic $\mathrm{Al}_{2} \mathrm{O}_{3}-\mathrm{ZrO}_{2}-\mathrm{TiC}$ [59-61]. A high-energy laser beam increasing the temperature on the surface promotes the particle interaction to each other before sintering together, while the material on the grain borderline continues to diffuse into the pores, stimulating densification activities. Since SLS is characterized by a high heating rate and short holding time, it results as an excellent alternative in producing scaffolds supported by low-dimensional nanomaterials such as graphene and carbon nanotubes [62].

\subsection{Electrospinning}

Nanodimensional high specific surface area devices can be fabricated with bioactive loaded polymer through the electrospinning technique [63]. In a conventional electrospinning system, generally comprising of a high-voltage power supply, syringe, pump and a collector, polymeric nanofibers, inorganic nanofibers, and composite nanofibers are ejected into a sequence of droplets forming steady fiber $[64,65]$.

\subsection{Stereolithography and Digital Light Processing}

Stereolithographic (SLA) and Digital Light Processing 3DP allow the layer by layer realization of 3D mesoporous stuff by cross-linking photo-sensitive materials using laser light or digital light projection technique, respectively [66]. The curing stereolithographic step, both in single-photon and two-photon polymerization, is actuated by tuning the incidence, the intensity, and the duration of near-infrared, visible or UV light.

\subsection{Two-Photon Polymerization}

While single-photon polymerization requires one-photon absorption, in TPP, the molecule simultaneously absorbs two photons. By employing a focused femtosecond near-IR, TPP stereolithography, processing biocompatible synthetic or natural hydrogels or polymers, grants the ultra-fast production of 3D structures with submicron resolution [67].

\section{Applications of 3DP Mesoporous Material for Drug Delivery}

Doing a search on the Web of Science and on Pubmed at the beginning of June 2020, resulted that in the last decades a fair number of publications are strictly related to the specific topic covered in this review and, more in details, related to mesoporous 3D printed materials for drug delivery applications. As highlighted in Table 1, most of the results focalized on the application of these 3D porous materials for tissue engineering bone substitute realization. Their porosity, by mimicking the bone structure, allows nutrient transport, waste removal, cell migration, angiogenesis and differentiation phenomena, assisting bone regeneration in bone defects related to traumatic events or pathologies.

\subsection{Bone Regeneration}

\subsubsection{Growth Factors and Peptides}

Several FDA approved growth factors as BMP-2 have been used in clinics for bone and cartilage regeneration. In a mesoporous bioactive glass (MBG) covered silicate 1393 bioactive glass scaffolds candidate for bone repairing application, BMP-2 release was higher than that of DNA and dexamethasone. MBG successfully physically absorbed and released the active molecule without upsetting its pharmacological activity [68]. Fish hydrogel-based mesoporous strontium-doped calcium silicate scaffolds were proved to be efficient BMP-2 carriers for in vitro human Wharton jelly mesenchymal stem cell differentiation [69]. Customized 3D-printed osteoinductive implants were realized integrating porous silicon BMP-2 carriers within a 3D-printed PCL patient-specific implant [70]. FDM 3D MesoCS scaffolds combined with PCL were presented as odontoinductive biomaterial with efficient BMP-2 delivery capability [71]. In vitro tested BMP-2 pre-loaded mesoporous calcium silicate/PCL scaffolds, 
even if not suitable for clinical applications, exhibited high biocompatibility and sustained drug delivery pattern compared to the ones directly immersed with BMP-2 after the FDM fabrication [45].

As some authors reported some relevant side-effect related to the use of BMP-2 [72], $3 \mathrm{D}$ dipyridamole-coated hydroxyapatite $(\mathrm{HA}) /$ beta-tri-calcium phosphate $(\beta-\mathrm{TCP})$ scaffolds were successfully used to promote bone regeneration in critical bone defects as well as BMP-2 [73].

Since vascularization is a key step of the osteogenesis process, 3DP dimethyloxallyl glycine loaded MBGs and poly(3-hydroxybutyrate-co-3-hydroxyhexanoate) polymers scaffolds and results showed that dimethyloxallyl glycine was effectively released improving angiogenesis and osteregeneration in the bone faults [74]. Vascular endothelial growth factor (VEGF), was well encapsulated in chitosan/dextran sulfate microparticles and mixed into a calcium phosphate paste for the 3D plotting of growth factor loaded calcium-phosphate-based scaffolds applicable for bone tissue engineering [75].

Materials for tissue regeneration can be functionalized with engineered peptides able to regulate bone healing and regeneration. In vitro tests with naringin and calcitonin gene-related peptide-loaded 3DP MBG/sodium alginate/gelatin scaffolds showed that their high porosity assure efficient sustained drug delivery [76]. Peptide osteostatin and $\mathrm{Zn}^{2+}$ ions loaded meso-macroporous 3D scaffolds based on MBGs, exhibited a synergistic effect improving human mesenchymal stem cell growth, promoting their osteogenic differentiation [77]. SLS 3DP poly(3-hydroxybutyrate) scaffolds, when post-printing loaded with osteogenic growth peptide, exhibited the ability to support cell growth and tissue restoration [78].

\subsubsection{Anti-Inflammatory and Antibiotics}

Since any bone loss such as that following trauma, bone diseases and surgery, potentially provides suitable conditions for the onset of chronic infections or biofilm, it is highly desired the realization of anti-inflammatory and antibiotic-eluting scaffolds for sustained release without side effect in osteointegration, osteogenesis and osteoconduction processes. Dexamethasone loaded mesoporous $\mathrm{CaSiO}_{3} /$ calcium sulfate hemihydrate (MCS/CSH) cement scaffolds have been realized by 3D printing. Compared to the tissue culture plates control, MCS/CSH scaffolds exhibited a good in vitro OCT-1 cells response, an extra balanced degradation rate and capacities to slowly release the uploaded drug in targeted sites [79].

3DP high porosity dual-drug delivery layered MBG/sodium-alginate (SA)-SA scaffolds were successfully fabricated enriching the printing step with SA cross-linking. They resulted able to stimulate proliferation and osteogenic differentiation of human bone marrow-derived mesenchymal stem cells, furthermore, bovine serum albumin (BSA) and ibuprofen were successfully loaded in SA layer and the MBG of MBG/SA layer, respectively, resulting in a quite fast BSA release due to the macroporous network of $\mathrm{SA}$, and in a constant release of ibuprofen due to the retention effect of the mesoporous channels of MBG [80].

It is well-known that inflammation phenomena thwart bone regeneration in transplanted loci and the local effect of short-term corticosteroid administration increase the effectiveness of bone tissue engineering [81]. Dexamethasone-loaded polydopamine-functionalized MBG was incorporated into polyglycolic acid/poly-1-lactic acid (PGPL) to fabricate a 3D mesoporous scaffold via laser additive manufacturing able to stimulate cell differentiation, biomineralization [82]. Loaded dexamethasone electrospun fibrous scaffolds of PCL-gelatin, incorporating MBG nanoparticles (MBGn), were presented excellent valid 3D platforms for bone tissue engineering [83].

In the case of dexamethasone-loaded 3DP strontium-containing MBG scaffolds the mesoporous matrix with enhanced mechanical strength to ensure great bone-growing bioactivity together with marked drug delivery capability [84]. 3DP scaffolds realized by using MBG and concentrated alginate pastes efficiently delivered dexamethasone in an in vitro test with human bone marrow-derived mesenchymal stem cells thanks to their matrix characterized by a well-ordered network of nano-channels and micro and macro-pores [85]. Poly(1,8-octanediol-co-citrate) and $\beta$-tricalcium phosphate $\left(\beta-\mathrm{Ca}_{3}\left(\mathrm{PO}_{4}\right)_{2}\right)$, together with ibuprofen-loaded $\mathrm{SiO}_{2}$ were made-up by micro-droplet jetting 
3DP technique. Their hierarchically macro/mesoporous extremely interconnected pore matrix made them a valid antimicrobial bioengineered solution for bone regeneration [86,87].

The antimicrobials local application usually provides higher drug delivery than those attained with the intravenous application [88,89] and many 3DP macro/meso-porous composite scaffolds, are at the moment used to support a reproducible safe a better and well-regulated in situ antibiotics delivery. Some doxorubicin-loaded 3DP magnetic $\mathrm{Fe}_{3} \mathrm{O}_{4}$ nanoparticles containing mesoporous bioactive glass/polycaprolactone composite scaffolds enhanced osteogenic activity also assured sustained local anticancer delivery coupled with magnetic hyperthermia treatment [90].

Multidrug-loaded scaffold undoubtedly improves the applicability of 3D rapid prototype implants to ward off biofilm growth and drug resistance. Antibiotics are usually locally delivered via PMMA bone cement spacers [91,92] compatible with a restricted number of antibiotics and characterized by having low release profiles. Mesoporous bioactive glass/metal-organic framework and macro/meso-porous composite bioactive ceramics bound with poly (3-hydroxybutyrate-co-3-hydroxyhexanoate) scaffolds loaded with high dosages of isoniazid and/or rifampin, anti- tuberculosis drugs, had good biocompatibility and bioactivity when tested for long-term therapy after osteoarticular tuberculosis debridement surgery. Hierarchical 3DP multidrug scaffolds built with nanocomposite bioceramic and PVA were coated of gelatin-glutaraldehyde (Gel-Glu). Levofloxacin was loaded into the mesopores of the bioceramic part, vancomycin was packed into the biopolymer portion while rifampin in the external layer of Gel-Glu. The early delivery of rifampin followed by a sustained release of vancomycin and levofloxacin, represented an excellent and encouraging alternative for bone infection management [93]. 3DP rifampin- and vancomycin-loaded calcium phosphate scaffolds, used in a mouse model implant-associated staphylococcus aureus bone infection, proved that the concomitant local delivery of rifampin and vancomycin significantly improves the outcomes of the implant compared to PMMA spacers which cannot carry rifampin [94]. Gelatine and Si-doped hydroxyapatite porous 3D scaffolds were successfully loaded with vancomycin since they were rapidly prototyped fabricated at room temperature and apart from by increasing in vitro pre-osteoblastic MC3T3-E1 cell differentiation they also inhibit bacterial growth [95].

\subsubsection{Metallic Ions and Trace Elements}

Recently, many metallic ions such as zinc, copper, silver, cerium, strontium and cobalt, were combined with bioactive glasses to improve osteogenesis and angiogenesis [96-98]. Silver, among all, is the one that stands out for its strong antibacterial qualities. Silver/graphene oxide homogeneous nanocomposites were modified on 3DP $\beta$-tricalcium phosphate bioceramic scaffolds leading to a bifunctional scaffold with, just test in vitro, antibacterial and osteogenic activity were realized and in vitro tested [99].

In addition to the direct effect that a drug-loaded on a scaffold can have at the implantation site, several authors highlighted that also the integration of trace elements such as strontium, zinc, magnesium, calcium, copper, boron and cerium in 3DP mesoporous bioactive glass scaffolds enhance in vitro and in vivo osteogenic and differentiation activity [100-102].

\subsection{Other Applications}

Apart from the numerous applications in the bone regeneration field, mesoporous 3DP scaffolds including also mesoporous elastomer characterized by ordered and aligned nanofibrillar architecture that can be rapidly managed into multifaceted objects are starting to be more and more widespread even in other branches of biomedical research and medical clinic [103].

Coaxial electrospinned silk fibroin-based scaffolds are successfully tested as a potential brain-derived neurotrophic factor and VEGF delivery carrier in nerve repair and reconstruction applications [104].

Anti-HIV-1 drugs, including emtricitabine, tenofovir disoproxil fumarate and efavirenz were successfully loaded in a 24-layered rectangular prism-shaped 3DP controlled release fixed-dose combination tablets able to control the intestinal release of the active molecules [105]. 
Table 1. Applications of 3DP porous materials for tissue engineering and bone substitute realization.

\begin{tabular}{|c|c|c|c|c|c|}
\hline Material & $\begin{array}{l}\text { 3D Printing } \\
\text { Method }\end{array}$ & Drug & $\begin{array}{l}\text { Drug Loading } \\
\text { Method }\end{array}$ & Application & Reference \\
\hline Mesoporous strontium substitution calcium silicate/recycled fish gelatin 3D cell-laden scaffold. & IP & \multirow{3}{*}{ BMP-2 } & DL & $\begin{array}{l}\text { Bone tissue engineering. } \\
\text { In vitro }\end{array}$ & [69] \\
\hline PCL 3DP patient-specific implant, with degradable porous silicon-based carriers. & SLA & & DL & $\begin{array}{l}\text { Bone graft for critical size bone } \\
\text { defects. } \\
\text { In vitro } \\
\end{array}$ & [70] \\
\hline Mesoporous calcium silicate 3DP scaffold. & FDM & & DL & $\begin{array}{l}\text { Bone regeneration. } \\
\text { In vitro } \\
\end{array}$ & [45] \\
\hline $\begin{array}{l}\text { Hierarchical 3D multidrug scaffolds based on nanocomposite bioceramic and PVA with an } \\
\text { external coating of gelatin-glutaraldehyde. }\end{array}$ & IP & Dipyridamole and BMP-2 & DL & $\begin{array}{l}\text { Bone tissue engineering. } \\
\text { In vivo (mice) }\end{array}$ & [73] \\
\hline Scaffold is composed of MBG and poly(3-hydroxybutyrate-co-3-hydroxyhexanoate) polymers. & IP & Dimethyloxallyl glycine & PL & $\begin{array}{l}\text { Angiogenesis and osteogenesis for } \\
\text { bone tissue engineering. } \\
\text { In vivo (rats) }\end{array}$ & [74] \\
\hline MBG with sodium alginate and gelatin. & IP & $\begin{array}{l}\text { Naringin and calcitonin } \\
\text { gene-related peptide }\end{array}$ & DL & $\begin{array}{l}\text { Bone repair. } \\
\text { In vitro }\end{array}$ & [76] \\
\hline MBG. & IP & Peptide osteostatin and $\mathrm{Zn}^{2+}$ ions & DL & $\begin{array}{l}\text { Bone grafts with enhanced } \\
\text { osteogenic capacity. } \\
\text { In vitro } \\
\end{array}$ & [77] \\
\hline Poly(3-hydroxybutyrate) scaffold. & SLS & $\begin{array}{l}\text { Osteogenic growth peptide and its } \\
\text { C-terminal sequence (10-14) }\end{array}$ & DL & $\begin{array}{l}\text { Bone tissue engineering. } \\
\text { In vitro } \\
\end{array}$ & [78] \\
\hline $\begin{array}{l}\text { Calcium phosphate cement scaffolds by 3D plotting with growth factors encapsulating } \\
\text { chitosan/dextran sulfate microparticles mixed into the paste. }\end{array}$ & IP & BSA and VEGF & PL & $\begin{array}{l}\text { Encapsulate growth factors in a } \\
\text { cement. } \\
\text { In vitro } \\
\end{array}$ & [75] \\
\hline Layered MBG/SA. & IP & BSA and ibuprofen & PL & $\begin{array}{l}\text { Stimulate human bone } \\
\text { mesenchymal stem cells (hBMSCs) } \\
\text { adhesion, proliferation and } \\
\text { osteogenic differentiation. } \\
\text { In vitro }\end{array}$ & [80] \\
\hline Integrate MBG with 3D printing basic 1393 bioactive glass scaffolds. & IP & Dexamethasone and BMP-2 & DL & $\begin{array}{l}\text { Bone repair and relative bone } \\
\text { disease treatment. } \\
\text { In vivo (rats) }\end{array}$ & [68] \\
\hline
\end{tabular}


Table 1. Cont

\begin{tabular}{|c|c|c|c|c|c|}
\hline Material & $\begin{array}{l}\text { 3D Printing } \\
\text { Method }\end{array}$ & Drug & $\begin{array}{l}\text { Drug Loading } \\
\text { Method }\end{array}$ & Application & Reference \\
\hline MBG is functionalized with polydopamine and PGPL. & SLS & \multirow{5}{*}{ Dexamethasone } & PL & $\begin{array}{l}\text { Osteogenic differentiation and } \\
\text { biomineralization. } \\
\text { In vitro }\end{array}$ & [82] \\
\hline Calcium sulfate hemihydrate cement is incorporated in mesoporous calcium silicate. & IP & & PL & $\begin{array}{c}\text { Bone tissue engineering. } \\
\text { In vitro } \\
\end{array}$ & [79] \\
\hline $\begin{array}{l}\text { Electrospun fibrous scaffolds of PCL-gelatin incorporating mesoporous bioactive } \\
\text { glass nanoparticles. }\end{array}$ & ES & & PL & $\begin{array}{l}\text { Bone regeneration. } \\
\text { In vivo (rats) }\end{array}$ & [83] \\
\hline MBG with strontium. & IP & & PL & $\begin{array}{l}\text { Bone regeneration. } \\
\text { In vitro }\end{array}$ & [84] \\
\hline Hierarchical scaffolds of MBG and concentrated alginate pastes. & IP & & PL & $\begin{array}{l}\text { Bone tissue engineering. } \\
\text { In vitro }\end{array}$ & [85] \\
\hline 3D magnetic $\mathrm{Fe}_{3} \mathrm{O}_{4}$ nanoparticles containing MBG/PCL composite scaffolds. & IP & Doxorubicin & PL & $\begin{array}{l}\text { Osteogenic activity, local anticancer } \\
\text { drug delivery and magnetic } \\
\text { hyperthermia. } \\
\text { In vitro }\end{array}$ & [90] \\
\hline $\begin{array}{l}\text { Hollow mesoporous structure of silica }\left(\mathrm{SiO}_{2}\right) \text { microspheres loaded in a } \\
\text { Poly(1,8-octanediol-co-citrate) and } \beta \text {-tricalcium phosphate scaffold. }\end{array}$ & IP & \multirow[t]{2}{*}{ Ibuprofen } & PL & $\begin{array}{c}\text { Bone regeneration of infected bone } \\
\text { defects. } \\
\text { In vitro }\end{array}$ & {$[86]$} \\
\hline Poly(1,8-octanediol-co-citrate) and $\beta$-tricalcium phosphate scaffold. & IP & & PL & $\begin{array}{l}\text { Bone defect repair. } \\
\text { In vitro }\end{array}$ & [87] \\
\hline MBG with MOFs and PCL. & IP & Isoniazid & PL & $\begin{array}{l}\text { Osteoarticular tuberculosis } \\
\text { treatment. } \\
\text { In vitro } \\
\end{array}$ & [106] \\
\hline Carboxylic MBG and methyl-functionalized mesoporous silica nanoparticles. & IP & Isoniazid and rifampin & PL & $\begin{array}{c}\text { Filler after surgical treatment of } \\
\text { osteoarticular tuberculosis. } \\
\text { In vivo (rabbits) }\end{array}$ & [107] \\
\hline $\begin{array}{l}\text { Hierarchical 3D multidrug scaffolds based on nanocomposite bioceramic and PVA with an } \\
\text { external coating of Gel-Glu. }\end{array}$ & IP & $\begin{array}{l}\text { Rifampin, levofloxacin and } \\
\text { vancomycin }\end{array}$ & PL & $\begin{array}{l}\text { Destroy Gram-positive and } \\
\text { Gram-negative bacteria biofilms for } \\
\text { local bone infection therapy. } \\
\text { In vitro }\end{array}$ & [93] \\
\hline 3D printed calcium phosphate scaffolds. & IP & Rifampin and vancomycin & PL & $\begin{array}{c}\text { Treat an implant-associated } \\
\text { Staphylococcus aureus bone } \\
\text { infection. } \\
\text { In vivo (mice) }\end{array}$ & [94] \\
\hline Porous 3-D scaffolds consisting of gelatine and Si-doped hydroxyapatite. & IP & Vancomycin & PL & $\begin{array}{l}\text { Pre-osteoblastic MC3T3-E1 cell } \\
\text { differentiation. } \\
\text { In vitro }\end{array}$ & [95] \\
\hline
\end{tabular}


Table 1. Cont

\begin{tabular}{|c|c|c|c|c|c|}
\hline Material & $\begin{array}{l}\text { 3D Printing } \\
\text { Method }\end{array}$ & Drug & $\begin{array}{l}\text { Drug Loading } \\
\text { Method }\end{array}$ & Application & Reference \\
\hline $\begin{array}{l}\beta \text {-tricalcium phosphate bioceramic scaffolds with a homogeneous nanocomposite made of } \\
\text { silver nanoparticles and graphene oxide. }\end{array}$ & IP & $\begin{array}{l}\text { Silver nanoparticles and graphene } \\
\text { oxide }\end{array}$ & PL & $\begin{array}{l}\text { Bone grafts with good antibacterial } \\
\text { performance. } \\
\text { In vitro }\end{array}$ & [99] \\
\hline Borosilicate MBG. & IP & Boron and silicon ions & PL & $\begin{array}{l}\text { Repair bone defects. } \\
\text { In vivo (rats) }\end{array}$ & [100] \\
\hline 3D porous composite scaffolds made of cerium oxide, mesoporous calcium silicate and PCL. & IP & Cerium ions & PL & $\begin{array}{l}\text { Bone regeneration. } \\
\text { In vitro }\end{array}$ & [101] \\
\hline MBG with strontium. & IP & Strontium ions & PL & $\begin{array}{l}\text { Bone regeneration. } \\
\text { In vivo (rats) }\end{array}$ & [102] \\
\hline MBG modified $\beta$-tricalcium phosphate. & IP & $\begin{array}{l}\text { Calcium, phosphorus and silicon } \\
\text { ions }\end{array}$ & PL & $\begin{array}{l}\text { Angiogenesis and osteogenesis for } \\
\text { bone tissue engineering. } \\
\text { In vivo (rabbits) }\end{array}$ & [108] \\
\hline Mesoporous calcium silicate 3D-printed scaffold. & IP & BMP-2 & PL & $\begin{array}{l}\text { Odontoinductive biomaterial in } \\
\text { regenerative endodontics. } \\
\text { In vitro }\end{array}$ & [71] \\
\hline Silk fibroin porous scaffold. & ES & $\begin{array}{l}\text { Brain-derived neurotrophic factor } \\
\text { and VEGF }\end{array}$ & PL & $\begin{array}{l}\text { Cavernous nerve regeneration. } \\
\text { In vivo (rats) }\end{array}$ & [104] \\
\hline $\begin{array}{l}\text { Nanostructured ordered mesoporous elastomers composed of molecular double networks } \\
\text { (poly(ethylene oxide)-poly(propylene oxide)-poly(ethylene oxide) pluronic copolymers, } \\
\text { and PMMA. }\end{array}$ & IP & Ibuprofen and vancomycin & DL & $\begin{array}{c}\text { Biomedical and engineering } \\
\text { applications as the need for high } \\
\text { mechanical performance coexisting } \\
\text { with precise nano-microstructural } \\
\text { features. } \\
\text { In vitro }\end{array}$ & [103] \\
\hline Humic acid-polyquaternium 10 tablet. & IP & $\begin{array}{l}\text { Efavirenz, tenofovir disoproxil } \\
\text { fumarate and emtricitabine }\end{array}$ & PL & $\begin{array}{l}\text { Anti-HIV-1 controlled drug } \\
\text { delivery. } \\
\text { In vivo (pigs) }\end{array}$ & [105] \\
\hline Mesoporous iron oxide nanoraspberry inside microneedles. & DLP & Minoxdil & DL & $\begin{array}{l}\text { Treatment of androgenetic alopecia. } \\
\text { In vivo (mice) }\end{array}$ & [109] \\
\hline Porous poly(ethylene glycol) dimethacrylate devices. & TPP & Rhodamine B as model drug & PL & $\begin{array}{l}\text { Different biomedical applications. } \\
\text { In vitro }\end{array}$ & [110] \\
\hline
\end{tabular}




\section{Conclusions}

For many years, 3D devices have been assisting research in very different areas, ranging from simple cell cultures to tissue engineering and drug delivery applications. 2D cell culture represents a chief tool in molecular and cellular biology due to its fast, ease, reproducibility and cheap distinctive characteristic. However, it is now universally accepted that 2D cell culture methods understate the live cells in vivo setting unlike reported for last-generation 3D biomaterials which, on the contrary, are able to mimic in a much more realistic way the environment required for a whole range of biomedical and clinical applications. The development of three-dimensional supports has even greater resonance in tissue engineering and regenerative medicine applications since, in those cases, the function of tissues or organs must be restored ensuring the spatial and functional interconnection between different cell types, in order to guarantee the exchange of gas, nutrients or drugs and the elimination of waste products. In this review, we wanted to highlight how these characteristics can be optimized by merging together the need to provide solid supports capable of assisting cell growth at the level of tissue and organ and, at the same time, the right degree of porosity of the materials that in the specific case of 3D biomaterials offers a whole series of drug delivery capabilities worthy of study and implementation. The way an active molecule is carried to a specific region or cellular type can impact on its interaction efficacy. Each drug has a therapeutic window in which health benefits must be maximized and side effects minimized. This need has materialized in the ever-stricter demand of a multidisciplinary approach for the implementation of new materials and methods for an effective in vitro and in vivo drug delivery. Materials science, chemistry and micro/nanofabrication offer both original and effective solutions applicable in research and clinical areas. The rapid and often inexpensive fabrication of 3DP structures enhances the performance of devices no longer used only as structural supports for tissue regeneration and differentiation thanks to the optimization of their intrinsic and tuneable porosity. 3DP mesoporous devices allow an effective drug delivery of personalized therapy, customizable both from the geometric point of view and from the point of view of pharmacological requests for each individual patient. With the topics covered in this review, we want to highlight how 3D printing techniques allow the production of CAD designing structures that fully correspond to the request of each patient in response to needs following trauma or pathologies. The future implementation of new biodegradable biopolymers and of multi-step etching processes for post-printing functionalization/modification, will also allow more efficient drug delivery application of scaffolds as the 3D EBM produced ones, by conferring them the not-yet optimized degree of mesoporosity.

Author Contributions: T.L., F.S., M.A. and E.d.F. conceived the review, analyzed the data of literature and wrote the paper. All authors have read and agreed to the published version of the manuscript.

Funding: This research received no external funding.

Conflicts of Interest: The authors declare no conflict of interest.

\section{References}

1. Anselmo, A.C.; Gokarn, Y.; Mitragotri, S. Non-invasive delivery strategies for biologics. Nat. Rev. Drug Discov. 2019, 18, 19-40. [CrossRef]

2. Thabet, Y.; Klingmann, V.; Breitkreutz, J. Drug Formulations: Standards and Novel Strategies for Drug Administration in Pediatrics. J. Clin. Pharmacol. 2018, 58, S26-S35. [CrossRef]

3. Moon, C.; Smyth, H.D.C.; Watts, A.B.; Williams, R.O. Delivery Technologies for Orally Inhaled Products: An Update. AAPS PharmSciTech 2019, 20, 117. [CrossRef] [PubMed]

4. Santos, A.; Veiga, F.; Figueiras, A. Dendrimers as Pharmaceutical Excipients: Synthesis, Properties, Toxicity and Biomedical Applications. Materials 2019, 13, 65. [CrossRef] [PubMed]

5. Palazzolo, S.; Bayda, S.; Hadla, M.; Caligiuri, I.; Corona, G.; Toffoli, G.; Rizzolio, F. The Clinical Translation of Organic Nanomaterials for Cancer Therapy: A Focus on Polymeric Nanoparticles, Micelles, Liposomes and Exosomes. Curr. Med. Chem. 2018, 25, 4224-4268. [CrossRef] [PubMed] 
6. Limongi, T.; Rocchi, A.; Cesca, F.; Tan, H.; Miele, E.; Giugni, A.; Orlando, M.; Perrone Donnorso, M.; Perozziello, G.; Benfenati, F.; et al. Delivery of Brain-Derived Neurotrophic Factor by 3D Biocompatible Polymeric Scaffolds for Neural Tissue Engineering and Neuronal Regeneration. Mol. Neurobiol. 2018, 55, 8788-8798. [CrossRef] [PubMed]

7. Abu, B.; Mohd Salman, K.; Muhammad Zafar, I.; Mohd Sajid, K. Tumor-Targeted Drug Delivery by Nanocomposites. Curr. Drug Metab. 2020, 21, 1-15. [CrossRef]

8. Dianzani, C.; Foglietta, F.; Ferrara, B.; Rosa, A.C.; Muntoni, E.; Gasco, P.; Della Pepa, C.; Canaparo, R.; Serpe, L. Solid lipid nanoparticles delivering anti-inflammatory drugs to treat inflammatory bowel disease: Effects in an in vivo model. World J. Gastroenterol. 2017, 23, 4200-4210. [CrossRef] [PubMed]

9. Arruebo, M. Drug delivery from structured porous inorganic materials. WIREs Nanomed. Nanobiotechnol. 2012, 4, 16-30. [CrossRef]

10. Choi, Y.; Kim, J.; Yu, S.; Hong, S. pH- and temperature-responsive radially porous silica nanoparticles with high-capacity drug loading for controlled drug delivery. Nanotechnology 2020, 31, 335103. [CrossRef]

11. Hongfei, L.; Jie, Z.; Pengyue, B.; Yueping, D.; Jiapeng, W.; Yi, D.; Yang, Q.; Ying, X. Establishment and In Vitro Evaluation of Porous Ion-responsive Targeted Drug Delivery System. Protein Pept. Lett. 2020, 27, 1-12. [CrossRef]

12. Ahuja, G.; Pathak, K. Porous carriers for controlled/modulated drug delivery. Indian J. Pharm. Sci. 2009, 71, 599-607. [CrossRef] [PubMed]

13. Chowdhury, A.H.; Salam, N.; Debnath, R.; Islam, S.M.; Saha, T. Chapter 8-Design and Fabrication of Porous Nanostructures and Their Applications. In Nanomaterials Synthesis; Beeran Pottathara, Y., Thomas, S., Kalarikkal, N., Grohens, Y., Kokol, V., Eds.; Elsevier: Amsterdam, The Netherlands, 2019; pp. 265-294. [CrossRef]

14. Solano, V.; Vega-Baudrit, J. Micro, Meso and Macro Porous Materials on Medicine. J. Biomater. Nanobiotechnol. 2015, 6, 247-256. [CrossRef]

15. Seaton, N.A. Determination of the connectivity of porous solids from nitrogen sorption measurements. Chem. Eng. Sci. 1991, 46, 1895-1909. [CrossRef]

16. Aquib, M.; Farooq, M.A.; Banerjee, P.; Akhtar, F.; Filli, M.S.; Boakye-Yiadom, K.O.; Kesse, S.; Raza, F.; Maviah, M.B.J.; Mavlyanova, R.; et al. Targeted and stimuli-responsive mesoporous silica nanoparticles for drug delivery and theranostic use. J. Biomed. Mater. Res. Part A 2019, 107, 2643-2666. [CrossRef] [PubMed]

17. Guimarães, R.S.; Rodrigues, C.F.; Moreira, A.F.; Correia, I.J. Overview of stimuli-responsive mesoporous organosilica nanocarriers for drug delivery. Pharmacol. Res. 2020, 155, 104742. [CrossRef]

18. Yu, Q.; Deng, T.; Lin, F.-C.; Zhang, B.; Zink, J.I. Supramolecular Assemblies of Heterogeneous Mesoporous Silica Nanoparticles to Co-deliver Antimicrobial Peptides and Antibiotics for Synergistic Eradication of Pathogenic Biofilms. ACS Nano 2020, 14, 5926-5937. [CrossRef]

19. Quinlan, E.; López-Noriega, A.; Thompson, E.M.; Hibbitts, A.; Cryan, S.A.; O’Brien, F.J. Controlled release of vascular endothelial growth factor from spray-dried alginate microparticles in collagen-hydroxyapatite scaffolds for promoting vascularization and bone repair. J. Tissue Eng. Regen. Med. 2017, 11, 1097-1109. [CrossRef]

20. Laurenti, M.; Lamberti, A.; Genchi, G.G.; Roppolo, I.; Canavese, G.; Vitale-Brovarone, C.; Ciofani, G.; Cauda, V. Graphene Oxide Finely Tunes the Bioactivity and Drug Delivery of Mesoporous ZnO Scaffolds. ACS Appl. Mater. Interfaces 2019, 11, 449-456. [CrossRef]

21. Vallet-Regí, M.; Balas, F.; Arcos, D. Mesoporous Materials for Drug Delivery. Angew. Chem. Int. Ed. 2007, 46, 7548-7558. [CrossRef]

22. Sengottuvelan, A.; Mederer, M.; Boccaccini, A.R. Preparation and characterization of mesoporous calcium-doped silica-coated $\mathrm{TiO} 2$ scaffolds and their drug releasing behavior. Int. J. Appl. Ceram. Technol. 2018, 15, 892-902. [CrossRef]

23. Sun, Y.; Han, X.; Wang, X.; Zhu, B.; Li, B.; Chen, Z.; Ma, G.; Wan, M. Sustained Release of IGF-1 by 3D Mesoporous Scaffolds Promoting Cardiac Stem Cell Migration and Proliferation. Cell. Physiol. Biochem. 2018, 49, 2358-2370. [CrossRef] [PubMed]

24. Boccardi, E.; Philippart, A.; Juhasz-Bortuzzo, J.A.; Beltrán, A.M.; Novajra, G.; Vitale-Brovarone, C.; Spiecker, E.; Boccaccini, A.R. Uniform Surface Modification of 3D Bioglass $\left({ }^{\circledR}\right)$-Based Scaffolds with Mesoporous Silica Particles (MCM-41) for Enhancing Drug Delivery Capability. Front. Bioeng. Biotechnol. 2015, 3, 177. [CrossRef] [PubMed] 
25. Davis, M.E. Ordered porous materials for emerging applications. Nature 2002, 417, 813-821. [CrossRef]

26. Marcos-Hernández, M.; Villagrán, D. 11-Mesoporous Composite Nanomaterials for Dye Removal and Other Applications. In Composite Nanoadsorbents; Kyzas, G.Z., Mitropoulos, A.C., Eds.; Elsevier: Amsterdam, The Netherlands, 2019; pp. 265-293. [CrossRef]

27. Pellicer, E.; Cabo, M.; Solsona, P.; Suriñach, S.; Baró, M.; Sort, J. Nanocasting of Mesoporous In-TM (TM = Co, Fe, Mn) Oxides: Towards 3D Diluted-Oxide Magnetic Semiconductor Architectures. Adv. Funct. Mater. 2013, 23, 900-911. [CrossRef]

28. Yonemoto, B.T.; Hutchings, G.S.; Jiao, F. A General Synthetic Approach for Ordered Mesoporous Metal Sulfides. J. Am. Chem. Soc. 2014, 136, 8895-8898. [CrossRef]

29. Savic, S.; Vojisavljević, K.; Počuča-Nešić, M.; Živojević, K.; Mladenovic, M.; Knezevic, N. Hard Template Synthesis of Nanomaterials Based on Mesoporous Silica. Metall. Mater. Eng. 2018, 24. [CrossRef]

30. Zhao, T.; Elzatahry, A.; Li, X.; Zhao, D. Single-micelle-directed synthesis of mesoporous materials. Nat. Rev. Mater. 2019, 4, 775-791. [CrossRef]

31. Lokupitiya, H.N.; Jones, A.; Reid, B.; Guldin, S.; Stefik, M. Ordered Mesoporous to Macroporous Oxides with Tunable Isomorphic Architectures: Solution Criteria for Persistent Micelle Templates. Chem. Mater. 2016, 28, 1653-1667. [CrossRef]

32. Zuo, X.; Xia, Y.; Ji, Q.; Gao, X.; Yin, S.; Wang, M.; Wang, X.; Qiu, B.; Wei, A.; Sun, Z.; et al. Self-Templating Construction of 3D Hierarchical Macro-/Mesoporous Silicon from OD Silica Nanoparticles. ACS Nano 2017, 11, 889-899. [CrossRef]

33. Manzano, M.; Colilla, M.; Vallet-Regí, M. Drug delivery from ordered mesoporous matrices. Expert Opin. Drug Deliv. 2009, 6, 1383-1400. [CrossRef] [PubMed]

34. Sun, T.; Shan, N.; Xu, L.; Wang, J.; Chen, J.; Zakhidov, A.A.; Baughman, R.H. General Synthesis of 3D Ordered Macro-/Mesoporous Materials by Templating Mesoporous Silica Confined in Opals. Chem. Mater. 2018, 30, 1617-1624. [CrossRef]

35. Kang, Y.G.; Wei, J.; Shin, J.W.; Wu, Y.R.; Su, J.; Park, Y.S.; Shin, J.-W. Enhanced biocompatibility and osteogenic potential of mesoporous magnesium silicate/polycaprolactone/wheat protein composite scaffolds. Int. J. Nanomed. 2018, 13, 1107-1117. [CrossRef] [PubMed]

36. Wijk, A.; van Wijk, I. 3D Printing with Biomaterials: Towards a Sustainable and Circular Economy; IOS Press: Amsterdam, The Netherlands, 2015; pp. 1-85. [CrossRef]

37. Erokhin, K.S.; Gordeev, E.G.; Ananikov, V.P. Revealing interactions of layered polymeric materials at solid-liquid interface for building solvent compatibility charts for 3D printing applications. Sci. Rep. 2019, 9, 20177. [CrossRef]

38. Salea, A.; Prathumwan, R.; Junpha, J.; Subannajui, K. Metal oxide semiconductor 3D printing: Preparation of copper(ii) oxide by fused deposition modelling for multi-functional semiconducting applications. J. Mater. Chem. C 2017, 5, 4614-4620. [CrossRef]

39. Zhang, S.; Xing, M.; Li, B. Recent advances in musculoskeletal local drug delivery. Acta Biomater. 2019, 93, 135-151. [CrossRef]

40. Trofimov, A.D.; Ivanova, A.A.; Zyuzin, M.V.; Timin, A.S. Porous Inorganic Carriers Based on Silica, Calcium Carbonate and Calcium Phosphate for Controlled/Modulated Drug Delivery: Fresh Outlook and Future Perspectives. Pharmaceutics 2018, 10, 167. [CrossRef]

41. Liang, F.; Qin, L.; Xu, J.; Li, S.; Luo, C.; Huang, H.; Ma, D.; Li, Z.; Xu, J. A hydroxyl-functionalized 3D porous gadolinium-organic framework platform for drug delivery, imaging and gas separation. J. Solid State Chem. 2020, 289, 121544. [CrossRef]

42. Rawtani, D.; Agrawal, Y.K. Emerging Strategies and Applications of Layer-by-Layer Self-Assembly. Nanobiomedicine 2014, 1, 8. [CrossRef]

43. Vanderburgh, J.; Sterling, J.A.; Guelcher, S.A. 3D Printing of Tissue Engineered Constructs for In Vitro Modeling of Disease Progression and Drug Screening. Ann. Biomed. Eng. 2017, 45, 164-179. [CrossRef]

44. Charbe, N.B.; McCarron, P.A.; Lane, M.E.; Tambuwala, M.M. Application of three-dimensional printing for colon targeted drug delivery systems. Int. J. Pharm. Investig. 2017, 7, 47-59. [CrossRef] [PubMed]

45. Huang, K.-H.; Lin, Y.-H.; Shie, M.-Y.; Lin, C.-P. Effects of bone morphogenic protein-2 loaded on the 3D-printed MesoCS scaffolds. J. Formos. Med. Assoc. 2018, 117, 879-887. [CrossRef] [PubMed] 
46. Shim, J.-H.; Kim, M.-J.; Park, J.Y.; Pati, R.G.; Yun, Y.-P.; Kim, S.E.; Song, H.-R.; Cho, D.-W. Three-dimensional printing of antibiotics-loaded poly- $\varepsilon$-caprolactone/poly(lactic-co-glycolic acid) scaffolds for treatment of chronic osteomyelitis. Tissue Eng. Regen. Med. 2015, 12, 283-293. [CrossRef]

47. Visscher, L.E.; Dang, H.P.; Knackstedt, M.A.; Hutmacher, D.W.; Tran, P.A. 3D printed Polycaprolactone scaffolds with dual macro-microporosity for applications in local delivery of antibiotics. Mater. Sci. Eng. C Mater. Biol. Appl. 2018, 87, 78-89. [CrossRef] [PubMed]

48. Long, J.; Gholizadeh, H.; Lu, J.; Bunt, C.; Seyfoddin, A. Review: Application of Fused Deposition Modelling (FDM) Method of 3D Printing in Drug Delivery. Curr. Pharm. Des. 2016, 22, 433-439. [CrossRef]

49. Goole, J.; Amighi, K. 3D printing in pharmaceutics: A new tool for designing customized drug delivery systems. Int. J. Pharm. 2016, 499, 376-394. [CrossRef]

50. Goyanes, A.; Buanz, A.B.M.; Hatton, G.B.; Gaisford, S.; Basit, A.W. 3D printing of modified-release aminosalicylate (4-ASA and 5-ASA) tablets. Eur. J. Pharm. Biopharm. 2015, 89, 157-162. [CrossRef]

51. Cui, X.; Boland, T.; D'Lima, D.D.; Lotz, M.K. Thermal Inkjet Printing in Tissue Engineering and Regenerative Medicine. Recent Pat. Drug Deliv. Formul. 2012, 6, 149-155. [CrossRef]

52. Boehm, R.D.; Miller, P.R.; Daniels, J.; Stafslien, S.; Narayan, R.J. Inkjet printing for pharmaceutical applications. Mater. Today 2014, 17, 247-252. [CrossRef]

53. Mathew, E.; Pitzanti, G.; Larrañeta, E.; Lamprou, D.A. 3D Printing of Pharmaceuticals and Drug Delivery Devices. Pharmaceutics 2020, 12, 266. [CrossRef]

54. Ni, J.; Ling, H.; Zhang, S.; Wang, Z.; Peng, Z.; Benyshek, C.; Zan, R.; Miri, A.K.; Li, Z.; Zhang, X.; et al. Three-dimensional printing of metals for biomedical applications. Mater. Today Bio 2019, 3, 100024. [CrossRef] [PubMed]

55. Yang, Y.; Wang, G.; Liang, H.; Gao, C.; Peng, S.; Shen, L.; Shuai, C. Additive manufacturing of bone scaffolds. Int. J. Bioprint. 2019, 2019, 5. [CrossRef] [PubMed]

56. Du, Y.; Liu, H.; Yang, Q.; Wang, S.; Wang, J.; Ma, J.; Noh, I.; Mikos, A.G.; Zhang, S. Selective laser sintering scaffold with hierarchical architecture and gradient composition for osteochondral repair in rabbits. Biomaterials 2017, 137, 37-48. [CrossRef] [PubMed]

57. Kumaresan, T.; Gandhinathan, R.; Murugan, R.; Muthusamy, A.; Kamarajan, B. Design, analysis and fabrication of polyamide/ hydroxyapatite porous structured scaffold using selective laser sintering method for bio-medical applications. J. Mech. Sci. Technol. 2016, 30, 5305-5312. [CrossRef]

58. Gan, M.X.; Wong, C.H. Properties of selective laser melted spodumene glass-ceramic. J. Eur. Ceram. Soc. 2017, 37, 4147-4154. [CrossRef]

59. Bai, P.K.; Cheng, J.; Liu, B. Selective laser sintering of polymer-coated Al2O3/ZrO2/TiC ceramic powder. Trans. Nonferrous Metals Soc. China 2005, 15, 261-265.

60. Deckers Jan, P.; Shahzad, K.; Cardon, L.; Rombouts, M.; Vleugels, J.; Kruth, J.-P. Shaping ceramics through indirect selective laser sintering. Rapid Prototyp. J. 2016, 22, 544-558. [CrossRef]

61. Chang, S.; Li, L.; Lu, L.; Fuh, J.Y.H. Selective Laser Sintering of Porous Silica Enabled by Carbon Additive. Materials 2017, 10, 1313. [CrossRef]

62. Gao, C.; Feng, P.; Peng, S.; Shuai, C. Carbon nanotube, graphene and boron nitride nanotube reinforced bioactive ceramics for bone repair. Acta Biomater. 2017, 61, 1-20. [CrossRef]

63. Moulton, S.E.; Wallace, G.G. 3-dimensional (3D) fabricated polymer based drug delivery systems. J. Controll. Release 2014, 193, 27-34. [CrossRef]

64. Partheniadis, I.; Nikolakakis, I.; Laidmäe, I.; Heinämäki, J. A Mini-Review: Needleless Electrospinning of Nanofibers for Pharmaceutical and Biomedical Applications. Processes 2020, 8, 673. [CrossRef]

65. Contreras-Cáceres, R.; Cabeza, L.; Perazzoli, G.; Díaz, A.; López-Romero, J.M.; Melguizo, C.; Prados, J. Electrospun Nanofibers: Recent Applications in Drug Delivery and Cancer Therapy. Nanomaterials 2019, 9, 656. [CrossRef] [PubMed]

66. Melchels, F.P.W.; Feijen, J.; Grijpma, D.W. A review on stereolithography and its applications in biomedical engineering. Biomaterials 2010, 31, 6121-6130. [CrossRef] [PubMed]

67. Pereira, R.F.; Bártolo, P.J. 3D Photo-Fabrication for Tissue Engineering and Drug Delivery. Engineering 2015, 1, 90-112. [CrossRef]

68. Wang, H.; Deng, Z.; Chen, J.; Qi, X.; Pang, L.; Lin, B.; Adib, Y.T.Y.; Miao, N.; Wang, D.; Zhang, Y.; et al. A novel vehicle-like drug delivery $3 \mathrm{D}$ printing scaffold and its applications for a rat femoral bone repairing in vitro and in vivo. Int. J. Biol. Sci. 2020, 16, 1821-1832. [CrossRef] 
69. Yu, C.-T.; Wang, F.-M.; Liu, Y.-T.; Ng, H.Y.; Jhong, Y.-R.; Hung, C.-H.; Chen, Y.-W. Effect of Bone Morphogenic Protein-2-Loaded Mesoporous Strontium Substitution Calcium Silicate/Recycled Fish Gelatin 3D Cell-Laden Scaffold for Bone Tissue Engineering. Processes 2020, 8, 493. [CrossRef]

70. Rosenberg, M.; Shilo, D.; Galperin, L.; Capucha, T.; Tarabieh, K.; Rachmiel, A.; Segal, E. Bone Morphogenic Protein 2-Loaded Porous Silicon Carriers for Osteoinductive Implants. Pharmaceutics 2019, 11, 602. [CrossRef]

71. Huang, K.-H.; Chen, Y.-W.; Wang, C.-Y.; Lin, Y.-H.; Wu, Y.-H.A.; Shie, M.-Y.; Lin, C.-P. Enhanced Capability of Bone Morphogenetic Protein 2-loaded Mesoporous Calcium Silicate Scaffolds to Induce Odontogenic Differentiation of Human Dental Pulp Cells. J. Endod. 2018, 44, 1677-1685. [CrossRef]

72. James, A.W.; LaChaud, G.; Shen, J.; Asatrian, G.; Nguyen, V.; Zhang, X.; Ting, K.; Soo, C. A Review of the Clinical Side Effects of Bone Morphogenetic Protein-2. Tissue Eng. Part B Rev. 2016, 22, 284-297. [CrossRef]

73. Ishack, S.; Mediero, A.; Wilder, T.; Ricci, J.L.; Cronstein, B.N. Bone regeneration in critical bone defects using three-dimensionally printed $\beta$-tricalcium phosphate/hydroxyapatite scaffolds is enhanced by coating scaffolds with either dipyridamole or BMP-2. J. Biomed. Mater. Res. B Appl. Biomater. 2017, 105, 366-375. [CrossRef]

74. Min, Z.; Shichang, Z.; Chen, X.; Yufang, Z.; Changqing, Z. 3D-printed dimethyloxallyl glycine delivery scaffolds to improve angiogenesis and osteogenesis. Biomater. Sci. 2015, 3, 1236-1244. [CrossRef] [PubMed]

75. Akkineni, A.R.; Luo, Y.; Schumacher, M.; Nies, B.; Lode, A.; Gelinsky, M. 3D plotting of growth factor loaded calcium phosphate cement scaffolds. Acta Biomater. 2015, 27, 264-274. [CrossRef] [PubMed]

76. Wu, J.; Miao, G.; Zheng, Z.; Li, Z.; Ren, W.; Wu, C.; Li, Y.; Huang, Z.; Yang, L.; Guo, L. 3D printing mesoporous bioactive glass/sodium alginate/gelatin sustained release scaffolds for bone repair. J. Biomater. Appl. 2018, 33, 755-765. [CrossRef] [PubMed]

77. Heras, C.; Sanchez-Salcedo, S.; Lozano, D.; Peña, J.; Esbrit, P.; Vallet-Regi, M.; Salinas, A.J. Osteostatin potentiates the bioactivity of mesoporous glass scaffolds containing $\mathrm{Zn}^{2+}$ ions in human mesenchymal stem cells. Acta Biomater. 2019, 89, 359-371. [CrossRef] [PubMed]

78. Saska, S.; Pires, L.C.; Cominotte, M.A.; Mendes, L.S.; de Oliveira, M.F.; Maia, I.A.; da Silva, J.V.L.; Ribeiro, S.J.L.; Cirelli, J.A. Three-dimensional printing and in vitro evaluation of poly(3-hydroxybutyrate) scaffolds functionalized with osteogenic growth peptide for tissue engineering. Mater. Sci. Eng. C 2018, 89, 265-273. [CrossRef] [PubMed]

79. Pei, P.; Wei, D.; Zhu, M.; Du, X.; Zhu, Y. The effect of calcium sulfate incorporation on physiochemical and biological properties of 3D-printed mesoporous calcium silicate cement scaffolds. Microporous Mesoporous Mater. 2017, 241, 11-20. [CrossRef]

80. Fu, S.; Du, X.; Zhu, M.; Tian, Z.; Wei, D.; Zhu, Y. 3D printing of layered mesoporous bioactive glass/sodium alginate-sodium alginate scaffolds with controllable dual-drug release behaviors. Biomed. Mater. 2019, 14, 065011. [CrossRef]

81. Chihara, T.; Zhang, Y.; Li, X.; Shinohara, A.; Kagami, H. Effect of short-term betamethasone administration on the regeneration process of tissue-engineered bone. Histol. Histopathol. 2020, 35, 709-717. [CrossRef]

82. Xu, Y.; Hu, Y.; Feng, P.; Yang, W.; Shuai, C. Drug loading/release and bioactivity research of a mesoporous bioactive glass/polymer scaffold. Ceram. Int. 2019, 45, 18003-18013. [CrossRef]

83. El-Fiqi, A.; Kim, J.-H.; Kim, H.-W. Osteoinductive Fibrous Scaffolds of Biopolymer/Mesoporous Bioactive Glass Nanocarriers with Excellent Bioactivity and Long-Term Delivery of Osteogenic Drug. ACS Appl. Mater. Interfaces 2015, 7, 1140-1152. [CrossRef]

84. Zhang, J.; Zhao, S.; Zhu, Y.; Huang, Y.; Zhu, M.; Tao, C.; Zhang, C. Three-dimensional printing of strontium-containing mesoporous bioactive glass scaffolds for bone regeneration. Acta Biomater. 2014, 10, 2269-2281. [CrossRef]

85. Luo, Y.; Wu, C.; Lode, A.; Gelinsky, M. Hierarchical mesoporous bioactive glass/alginate composite scaffolds fabricated by three-dimensional plotting for bone tissue engineering. Biofabrication 2012, 5, 015005. [CrossRef] [PubMed]

86. Chen, F.; Song, Z.; Gao, L.; Hong, H.; Liu, C. Hierarchically macroporous/mesoporous POC composite scaffolds with IBU-loaded hollow $\mathrm{SiO} 2$ microspheres for repairing infected bone defects. J. Mater. Chem. B 2016, 4, 4198-4205. [CrossRef] [PubMed]

87. Gao, L.; Li, C.; Chen, F.; Liu, C. Fabrication and characterization of toughness-enhanced scaffolds comprising $\beta-\mathrm{TCP} / \mathrm{POC}$ using the freeform fabrication system with micro-droplet jetting. Biomed. Mater. 2015, 10, 035009. [CrossRef] 
88. Kluin, O.S.; van der Mei, H.C.; Busscher, H.J.; Neut, D. Biodegradable vs non-biodegradable antibiotic delivery devices in the treatment of osteomyelitis. Expert Opin. Drug Deliv. 2013, 10, 341-351. [CrossRef]

89. Kamboj, N.; Rodriguez, M.; Rahmani Ahranjani, R.; Prashanth, K.G.; Hussainova, I. Bioceramic scaffolds by additive manufacturing for controlled delivery of the antibiotic vancomycin. Proc. Est. Acad. Sci. 2019, 68, 185-190. [CrossRef]

90. Zhang, J.; Zhao, S.; Zhu, M.; Zhu, Y.; Zhang, Y.; Liu, Z.; Zhang, C. 3D-printed magnetic Fe3O4/MBG/PCL composite scaffolds with multifunctionality of bone regeneration, local anticancer drug delivery and hyperthermia. J. Mater. Chem. B 2014, 2, 7583-7595. [CrossRef] [PubMed]

91. Jaeblon, T. Polymethylmethacrylate: Properties and Contemporary Uses in Orthopaedics. J. Am. Acad. Orthop. Surg. 2010, 18, 297-305. [CrossRef] [PubMed]

92. Darouiche, R.O. Treatment of infections associated with surgical implants. N. Engl. J. Med. 2004, 350, 1422-1429. [CrossRef]

93. García-Alvarez, R.; Izquierdo-Barba, I.; Vallet-Regí, M. 3D scaffold with effective multidrug sequential release against bacteria biofilm. Acta Biomater. 2017, 49, 113-126. [CrossRef]

94. Inzana, J.A.; Trombetta, R.P.; Schwarz, E.M.; Kates, S.L.; Awad, H.A. 3D printed bioceramics for dual antibiotic delivery to treat implant-associated bone infection. Eur. Cell Mater. 2015, 30, 232-247. [CrossRef]

95. Martínez-Vázquez, F.J.; Cabañas, M.V.; Paris, J.L.; Lozano, D.; Vallet-Regí, M. Fabrication of novel Si-doped hydroxyapatite/gelatine scaffolds by rapid prototyping for drug delivery and bone regeneration. Acta Biomater. 2015, 15, 200-209. [CrossRef] [PubMed]

96. Philippart, A.; Gómez-Cerezo, N.; Arcos, D.; Salinas, A.J.; Boccardi, E.; Vallet-Regi, M.; Boccaccini, A.R. Novel ion-doped mesoporous glasses for bone tissue engineering: Study of their structural characteristics influenced by the presence of phosphorous oxide. Non-Cryst. Solids 2017, 455, 90-97. [CrossRef]

97. Hoppe, A.; Güldal, N.S.; Boccaccini, A.R. A review of the biological response to ionic dissolution products from bioactive glasses and glass-ceramics. Biomaterials 2011, 32, 2757-2774. [CrossRef]

98. Kaya, S.; Cresswell, M.; Boccaccini, A.R. Mesoporous silica-based bioactive glasses for antibiotic-free antibacterial applications. Mater. Sci. Eng. C 2018, 83, 99-107. [CrossRef]

99. Zhang, Y.; Zhai, D.; Xu, M.; Yao, Q.; Zhu, H.; Chang, J.; Wu, C. 3D-printed bioceramic scaffolds with antibacterial and osteogenic activity. Biofabrication 2017, 9, 025037. [CrossRef]

100. Qi, X.; Wang, H.; Zhang, Y.; Pang, L.; Xiao, W.; Jia, W.; Zhao, S.; Wang, D.; Huang, W.; Wang, Q. Mesoporous bioactive glass-coated $3 \mathrm{D}$ printed borosilicate bioactive glass scaffolds for improving repair of bone defects. Int. J. Biol. Sci. 2018, 14, 471-484. [CrossRef]

101. Zhu, M.; Zhang, J.; Zhao, S.; Zhu, Y. Three-dimensional printing of cerium-incorporated mesoporous calcium-silicate scaffolds for bone repair. J. Mater. Sci. 2016, 51, 836-844. [CrossRef]

102. Zhao, S.; Zhang, J.; Zhu, M.; Zhang, Y.; Liu, Z.; Tao, C.; Zhu, Y.; Zhang, C. Three-dimensional printed strontium-containing mesoporous bioactive glass scaffolds for repairing rat critical-sized calvarial defects. Acta Biomater. 2015, 12, 270-280. [CrossRef]

103. Rajasekharan, A.K.; Gyllensten, C.; Blomstrand, E.; Liebi, M.; Andersson, M. Tough Ordered Mesoporous Elastomeric Biomaterials Formed at Ambient Conditions. ACS Nano 2020, 14, 241-254. [CrossRef]

104. Zhang, Y.; Huang, J.; Huang, L.; Liu, Q.; Shao, H.; Hu, X.; Song, L. Silk Fibroin-Based Scaffolds with Controlled Delivery Order of VEGF and BDNF for Cavernous Nerve Regeneration. ACS Biomater. Sci. Eng. 2016, 2, 2018-2025. [CrossRef]

105. Siyawamwaya, M.; du Toit, L.C.; Kumar, P.; Choonara, Y.E.; Kondiah, P.P.P.D.; Pillay, V. 3D printed, controlled release, tritherapeutic tablet matrix for advanced anti-HIV-1 drug delivery. Eur. J. Pharm. Biopharm. 2019, 138, 99-110. [CrossRef]

106. Pei, P.; Tian, Z.; Zhu, Y. 3D printed mesoporous bioactive glass/metal-organic framework scaffolds with antitubercular drug delivery. Microporous Mesoporous Mater. 2018, 272, 24-30. [CrossRef]

107. Zhu, M.; Li, K.; Zhu, Y.; Zhang, J.; Ye, X. 3D-printed hierarchical scaffold for localized isoniazid/rifampin drug delivery and osteoarticular tuberculosis therapy. Acta Biomater. 2015, 16, 145-155. [CrossRef] [PubMed]

108. Zhang, Y.; Xia, L.; Zhai, D.; Shi, M.; Luo, Y.; Feng, C.; Fang, B.; Yin, J.; Chang, J.; Wu, C. Mesoporous bioactive glass nanolayer-functionalized 3D-printed scaffolds for accelerating osteogenesis and angiogenesis. Nanoscale 2015, 7, 19207-19221. [CrossRef] 
109. Fang, J.-H.; Liu, C.-H.; Hsu, R.-S.; Chen, Y.-Y.; Chiang, W.-H.; Wang, H.-M.D.; Hu, S.-H. Transdermal Composite Microneedle Composed of Mesoporous Iron Oxide Nanoraspberry and PVA for Androgenetic Alopecia Treatment. Polymers 2020, 12, 1392. [CrossRef]

110. Do, A.-V.; Worthington, K.S.; Tucker, B.A.; Salem, A.K. Controlled drug delivery from 3D printed two-photon polymerized poly(ethylene glycol) dimethacrylate devices. Int. J. Pharm. 2018, 552, 217-224. [CrossRef] 